\title{
Penerapan asuhan keperawatan dalam pemenuhan kebutuhan nyeri di RSIA sitti khadijah III Makassar
}

\author{
Zulfia Samiun \\ Universitas Muhammadiyah Makassar \\ Email : zulfia.samiun@unismuh.ac.id
}

\begin{abstract}
Abstrak
Kematian dan kesakitan ibu masih merupakan masalah kesehatan yang serius di negara berkembang. Menurut laporan World Health Organization (WHO) Tahun 2014 Angka Kematian Ibu (AKI) di dunia yaitu 289.000 jiwa dengan indonesia mencapai 190.000 per 100.000 kelahiran hidup. Ruptur perineum merupakan penyebab tingginya angka kematian ibu bersalin kedua setelah perdarahan. Hampir $90 \%$ ibu mengalami robekan perineum setelah persalinan. Salah satu dampak yang dirasakan pasien yang mengalami ruptur perineum yaitu terjadi gangguan rasa nyaman nyeri yang bila tidak segera diatasi akan menimbulkan efek membahayakan yang dapat menganggu proses penyembuhan luka ruptur perineum. Penelitian ini untuk menggambarkan asuhan keperawatan pada klien post partum normal dengan ruptur perieum dalam pemenuhan kebutuhan rasa nyaman nyeri. Menggunakan tehnik wawancara, observasi, pemeriksaan fisik dan status kesehatan. Hasil penelitian studi kasus ini didapatkan gangguan kebutuhan rasa nyaman nyeri pada Ny. R teratasi dengan kriteria : nyeri berkurang dengan skala 2 dan klien mampu melakukan manajemen penanganan nyeri.
\end{abstract}

Kata kunci : Askep post partum normal, Ruptur Perineum, Kebutuhan rasa nyaman (nyeri).

\begin{abstract}
Maternal mortality and illness is still a serious health problem in developing countries. According to the 2014 World Health Organization (WHO) report, the Maternal Mortality Rate (MMR) in the world was 289,000 with Indonesia reaching 190,000 per 100,000 live births. Perineal rupture is the cause of high rates of second maternal mortality after bleeding. Nearly $90 \%$ of women experience perineal tears after labor. One of the effects felt by patients who experience perineal rupture is that there is a comfortable feeling of pain which if not immediately treated will cause harmful effects that can disrupt the healing process of perineal rupture wounds. This study is to describe nursing care for normal postpartum clients with peripheral rupture in meeting the needs of comfort pain. Using interview techniques, observation, physical examination and health status. The results of this case study study found discomfort in the need for pain in Ny. R is resolved by criteria: pain decreases with scale 2 and the client is able to manage pain management.
\end{abstract}

Keywords : normal post partum nursing care, Perineal rupture, Need for comfort (pain). 


\section{Pendahuluan}

Persalinan merupakan proses pengeluaran janin yang terjadi pada kehamilan cukup bulan $(37-42 \mathrm{mg})$. Lahir spontan dengan presentasi belakang kepala yang berlangsung dalam 18 jam, tanpa komplikasi baik pada ibu maupun pada janin(Djami \& Indrayani, 2013). Proses persalinan hampir $90 \%$ yang mengalami robekan perineum, baik dengan atau tanpa episiotomy. (Antini, Darwanty, \& Trisnawati, 2016). Rupture perineum adalah perlukaan jalan lahir yang tejadi pada saat kelahiran bayi, baik menggunakan alat maupun tidak menggunakan alat (Rahayu, 2016).

Kementrian dan kesakitan ibu masih merupakan masalah kesehatan yang serius di negara berkembang. Menurut laporan World Health Organization (WHO) Tahun 2014 Angka Kematian Ibu (AKI) di dunia yaitu 289.000 jiwa. Beberapa negara memiliki AKI cukup tinggi seperti Afrika Sub-Sahara 179.000 jiwa, Asia Selatan 69.000 jiwa, dan Asia Tenggara 16.000 jiwa. Angka kematian ibu di negara-negara Asia Tenggara yaitu Indonesia 190 per 100.000 kelahiran hidup, Vietnam 49 per 100.000 kelahiran hidup, Thailand 26 per 100.000 kelahiran hidup. (WHO, 2014)

Menurut Profil Kesehatan Prov Sulsel (2015), Tahun 2012 jumlah kematian ibu yang dilaporkan menjadi 160 orang atau 110,26 per 100.000 kelahiran hidup, terdiri dari kematian ibu hamil 45 orang $(28,1 \%)$, kematian ibu bersalin 60 orang (40\%), kematian ibu nifas 55 orang (30\%).

Penelitian McPherson, Beggs, Sultan, dan Thatkar (2014) di Inggris bahwa jumlah kelahiran 16.920 diperkirakan $71,1 \%$ berisiko mengalami ruptur perineum.Berdasarkan data World Health Organization (WHO) pada tahun 2009 terjadi 2.7 kasus ruptur perineum pada ibu bersalin. Dari survey awal yang dilakukan penelitian jumlah kejadian ruptur perineum dari tahun 2013 ke tahun 2014 mengalami kenaikan sebesar 35.4\%. Di Asia ruptur perineum juga merupakan masalah yang cukup banyak dalam masyarakat, $50 \%$ dari kejadian ruptur perineum di Dunia terjadi di Asia (Rahayu, 2016).

Dari hasil data yang ditemukan peneliti di RSIA Sitti Khadijah III Muhammadiyah Mamajang. Jumlah kasus ruptur perineum pada tahun 2015 tercatat 100 orang yang mengalami peningkatan pada tahun 2016 yaitu 116 orang, sedangkan pada tahun 2017 bulan Januari - Juli jumlah kasus ruptur perineum yaitu 288 orang.

Faktor-faktor yang menyebabkan terjadinya ruptur perineum antara lain faktor ibu yang terdiri dari paritas, jarak kelahiran, cara mengedan yang tidak tepat, dan umur ibu. Faktor janin yang terdiri dari berat badan bayi barulahir dan presentasi. Faktor persalinan pervaginam terdiri dari ekstraksi forceps, ekstraksi vakum, trauma alat dan episiotomi, kemudian faktor penolong persalinan yaitu pimpinan persalinan yang tidak tepat. (Yugistyowati, Prawitasari, \& Sari, 2015). Salah satu dampak yang dirasakan pasien yang mengalami ruptur perineum yaitu terjadi gangguan rasa nyaman nyeri.

Menurut Internasional Association For Study Of Pain (IASP), Nyeri adalah sensori subjektif dan emosional yang tidak menyenangkan yang di dapat terkait dengan kerusakan jaringan aktual maupun potensial, atau menggambarkan kondisi terjadinya kerusakan (Saputra, 2013). Faktor-faktor yang mempengaruhi nyeri selama persalinan terdiri dari faktor fisik, sosial, dan psikososial Yang meliputi paritas, prosedur medik, kecemasan, kelelahan, ketakutan, dan mekanisme koping. Reaksi nyeri merupakan bentuk respon seseorang terhadap nyeri seperti ketakutan, gelisah, cemas, menangis (Djami \& Indrayani, 2013).

Berdasarkan data tersebut, penulis ingin melakukan penelitian studi kasus mengenai 
penerapan asuhan keperawatan pada $\mathrm{Ny}$. R dengan post partum normal : ruptur perineum dalam pemenuhan kebutuhan rasa nyaman (nyeri) di RSIA Sitti Khadijah III Makassar

\section{Metode}

\section{Lokasi dan Rancangan Penelitian}

Studi Kasus ini dilakukan di RSIA Sitti Khadijah III Makassar.Rancangan studi kasus yang digunakan adalah metode deskriptif dengan pendekatan studi kasus.Pengumpulan data dilakukan dengan menggunakan formatpengkajian.

\section{Populasi dan Sampel}

Populasi dalam studi kasus ini yaitu seluruh pasien post partum normal yang mengalami rupture perineum di RSIA Sitti Khadijah III Makassar.Teknik pengambilan sampel yaitu pasien yang memenuhi kriteria inklusi : pasien post partum normal dengan rupture perineum yang dirawat di RSIA Sitti Khadijah III Makassar, pasien ruptur perineum dengan gangguan kebutuhan rasa nyaman nyeri, dan bersedia menjadi responden.

\section{Alat Pengumpul Data}

Alat pengumpulan data dalam studi kasus ini menggunakan format pengkajian.

\section{Analisa Data}

Analisis data yang dilakukan pada penelitian ini adalah dengan mendeskripsikan informasi yang telah tersusun dan melakukan penarikan kesimpulan serta pengambilan tindakan.Data yang telah tersusun kemudian disajikan dalam bentuk narasi yang mudah dipahami.

\section{Hasil}

Evaluasi keperawatan dilakukan dengan cara mengevaluasi sejauhmana hasil dari tindakan keperawatan yang dilakukan tercapai dengan mengacu pada tujuan dan criteria hasil yang telah ditetapkan.

Keluhan utama yang didapatkan saat melakukan pengkajian yaitu nyeri pada daerah perineum akibat luka jahitan, klien mengatakan nyeri seperti tertusuk-tusuk, dan didapatkan klien menunjukkan angka 8 pada skala nyeri, nyeri yang dirasakan klien hilang timbul.

Dari pemeriksaan pada Ny. R didapatkan keadaan umumtingkat kesadaran pasien compos mentis.Dengan tanda-tanda vital klien, tekanan darah :100/60 mmHg, Nadi : 84 kali per menit, respirasi : 24 kali per menit, Suhu : $36,5{ }^{0} \mathrm{C}$. Pada pemeriksaan perineum, inspeksi : luka jahitan masih basah, tidak ada puss, terdapat lochea rubra berwarna merah muda, segar. Ruptur mengenai selaput lender vagina dan otot perinea transversalis, tetapi tidak mengenai spingter ani (ruptur perineum derajat II), tidak ada hematom, dan kemerahan, jumlah jahitan 2/4 pada perineum.Palpasi : adanya nyeri tekan pada perineum.

Dari hasil pengkajian di prioritaskan diagnosa keperawatan Ny. $R$ yaitu nyeri akut berhubungan dengan kerusakan jaringan akibat trauma pada perineum selama persalinan dan kelahiran ditandai dengandata Subjektif: klien mengatakan nyeri pada bekas jahitan, klien mengatakan nyeri seperti ditusuk-tusuk, klien mengatakan nyeri hilang timbul. Data Objektif : pasien tampak meringis, terdapat luka jahitan $2 / 4$, terdapat nyeri tekan, klien menunjukkan angka 8 pada skala nyeri, tanda-tanda vital, Tekanan darah : 100/60 mmHg, Nadi : 88 kali per menit, respirasi : 24 kali per menit, Suhu : $36,5{ }^{0} \mathrm{C}$.

Intervensi yang dibuat berdasarkan diagnosa keperawatan adalah sebagai berikut : 1) tentukan lokasi nyeri dengan rasional lokasi nyeri memberikan informasi tentang etiologi dan jenis nyeri yang dialami, 2) pantau TTV 
dengan rasional respon otonom terhadap nyeri dapat menyebabkan peningkatan tekanan darah, takikardia, napas cepat, berkeringat, dan dilatasi pupil, 3) nilai intensitas nyeri dengan menggunakan skala nyeri yang berbasis fakta dengan rasional nyeri dan intensitasnya merupakan pengalaman yang subjektif Penggunaan skala yang sama secara konsisten untuk menilai intensitas nyeri memungkinkan evaluasi efektivitas intervensi, 4) jelaskan faktor yang menurunkan nyeri dengan rasional faktor yang menurunkan nyeri memberikan informasi yang dapat digunakan ketika melaksanakan perencanaan keperawatan manajemen nyeri, 5) ajarkan tekhnik relaksasi (tekhnik nafas dalam) dengan rasional penatalaksanaan tekhnik relaksasi (tekhnik nafas dalam) mendukung dalam menurunkan rasa nyeri, 6) berikan posisi yang nyaman dengan rasional pemberian posisi yangnyaman mendukung kesejahteraan fisik dan psikososial sehingga menurunkan persepsi nyeri, 7) kolaborasi pemberian analgesikdengan rasional analgesik Biasanya yang paling efektif ketika diberikan sebelum nyeri terjadi atau menjadi berat.

Setelah melakukan implementasi ditemukan hasil masalah kebutuhan rasa nyaman (nyeri) pada Ny. R teratasi sesuai dengan tujuan dan kriteria hasil yang ditetapkan yaitu klien mengatakan nyeri berkurang, klien mengatakan sudah bisa beraktifitas, klien tampak tenang dan nyaman, klien menunjukkan angka 2 pada skala nyeri, tandatanda vital, Tekanan darah : 110/70 $\mathrm{mmHg}$, Nadi : 74 kali per menit, respirasi : 24 kali per menit, Suhu : $36,5^{\circ} \mathrm{C}$.

\section{Pembahasan}

Studi kasus mengenai penerapan asuhan keperawatan pada pasien post partum normal dengan rupture perineum dalam pemenuhan kebutuhan rasa nyaman (nyeri) pada $\mathrm{Ny}$. R telah dilaksanakan di RSIA Sitti Khadijah III
Makassar sesuai kriteri inklusi yang telah ditetapkan.

Berdasarkan pengkajian yang dilakukan pada Ny. R hari pertama post partum, didapatkan data : klien mengatakan nyeri pada bekas jahitan, skala nyeri 8 , nyeri dirasakan seperti tertusuk-tusuk, pasien tampak meringis, terdapat luka jahitan 2/4, terdapat nyeri tekan, tanda-tanda vital, Tekanan darah : 100/60 mmHg, Nadi : 88 kali per menit, respirasi : 24 kali per menit, Suhu : $36,5{ }^{\circ} \mathrm{C}$. Hal ini sejalan dengan penelitian yang dilakukan oleh Francisco (2013), bahwa terdapat 241 ibu post partum yang mengalami nyeri akibat ruptur perineum, dikarenakan adanya laserasi jalan lahir yang mengenai selaput lender vagina dan otot perinea transversalis yang terjadi pada kala II persalinan dan dapat membarikan rasa ketidak nyamanan (nyeri).

Berdasarkan hasil penelitian yang dilakukan Fitriani (2015) menunjukkan bahwa 90,5\% kejadian ruptur perineum diakibatkan oleh berat badan bayi lahir normal yang berkisar 2500-3500 gram. Hal ini sejalan dengan data yang peneliti temukan bahwa Ny. R mengalami rupture perineum TK II dengan BBBL 2805 gram.

Berdasarkan data - data dari hasil pengkajian yang dilakukan pada $\mathrm{Ny}$. $\mathrm{R}$, diagnosa keperawatan yang muncul adalah nyeri akut berhubungan dengan kerusakan jaringan akibat trauma pada perineum selama persalinan dan kelahiran.Hal ini sesuai dengan teori menurut Saputra (2013), bahwa diagnosa keperawatan yang berhubungan dengan masalah kebutuhan rasa nyaman (nyeri) pada pasien ruuptur perineum adalah nyeri akut berhubungan dengan kerusakan jaringan akibat trauma pada perineum selama persalinan dan kelahiran.

Menurut Nurarif dan Hardhi (2015), ada 7 rencana tindakan yang dapat dilakukan untuk nyeri akut berhubungan dengan kerusakan jaringan akibat trauma pada perineum selama 
persalinan dan kelahiran.Dalam menetapkan rencana tindakan penulis merujuk pada teori yeng relevan dan sesuai dengan situasi dan kondisi klien, dengan demikian penerapan antara tinjauan teori dan kasus sesuai.

Implementasi dilakukan berdasarkan intervensi yang telah ditetapkan. Pada Rencana tindakan peneliti telah menetapkan 7 intervensi yang akan dilakukan pada $\mathrm{Ny}$. R sesuai dengan teori menurut Nurarif dan Hardhi (2015).

Pada hari kedua implementasi, ada tiga implementasi yang tidak dilakukan yaitu 1) menentukan lokasi nyeri tidak dilakukan dikarenakan peneliti sudah mengetahui lokasi nyeri, 2) menjelaskan faktor yang menurunkan nyeri tidak dilakukan dikarenakan dihari pertama peneliti sudah menjelaskan bagaimana cara yag dapat menurunkan nyeri dan Ny. R mengerti, 3) memberikan posisi yang nyaman tidak dilakukan dikarenakan Ny. R sudah kooperati.

Pada hari ketiga implementasi, ada empat implementasi yang tidak dilakukan yaitu 1) menentukan lokasi nyeri tidak dilakukan dikarenakan peneliti sudah mengetahui lokasi nyeri, 2) menjelaskan faktor yang menurunkan nyeri tidak dilakukan dikarenakan dihari pertama peneliti sudah menjelaskan bagaimana carayag dapat menurunkan nyeri dan Ny. R mengerti, 3) memberikan posisi yang nyaman tidak dilakukan dikarenakan Ny. R sudah kooperati. 4) mengajarkan tekhnik relaksasi (tekhnik nafas dalam) tidak dilakukan dikarenakan $\mathrm{Ny}$. $\mathrm{R}$ sudah mampu melakukan sendiri dan berdasarkan tanda dan gejala skala nyeri 2 .

Pada kasus Ny. R dengan ruptur perineum setelah dilakukan evaluasi selama 3 hari, klien mengatakan nyeri berkurang, klien mengatakan sudah bisa beraktifitas, klien tampak tenang dan nyaman, klien menunjukkan angka 2 pada skala nyeri, tandatanda vital, Tekanan darah : 110/70 mmHg,
Nadi : 74 kali per menit, respirasi : 24 kali per menit, Suhu : $36,5{ }^{\circ} \mathrm{C}$. Sedangkan tujuan dan kriteria hasil yang ingin dicapai berdasarkan teori adalah mampu mengontrol nyeri (tahu penyebab nyeri, mampu menggunakan tehnik nonfarmakologi untuk mengurangi nyeri, mencari bantuan), melaporkan bahwa nyeri berkurang dengan menggunakan manajemen nyeri, mampu mengenali nyeri (skala, intensitas, frekuensi dan tanda nyeri), mengatakan rasa nyaman setelah nyeri berkurang.

Dengan demikian diagnosa keperawatan nyeri akut berhubungan dengan kerusakan jaringan akibat trauma pada perineum selama persalinan dan kelahiran teratasi.

\section{Kesimpulan}

Dalam melakukan pengkajian keperawatan pada Ny. R, peneliti menggunakan beberapa metode yaitu wawancara, observasi, pemeriksaan fisik, dan studi dokumentasi yang bersumber dari klien, keluarga, catatan medis, hasil pemeriksaan diagnostic, petugas kesehatan lain dan kepustakaan. Diagnosa keperawatan yang muncul pada Ny.R adalah nyeri akut berhubungan dengan kerusakan jaringan akibat trauma pada perineum selama persalinan dan kelahiran.Rencana tindakan pada $\mathrm{Ny}$. R dengan rupture perineum di susun sesuai teori dari diagnosa keperawatan yang muncul. Dalam pelaksanaan tindakan keperawatan pada Ny. R dilakukan sesuai dengan rencana keperawatan yang telah ditetapkan namun ada beberapa rencana tindakan yang tidak dilakukan dikarenakan keterbatasan sarana dan prasarana.Setelah melakukan asuhan keperawatan, masalah keperawatan pada Ny.R teratasi sesuai dengan tujuan dan kriteria hasil yang ditetapkan.

\section{Saran}

Adapun saran dari penelitian ini yaitu dalam melakukan pengkajian keperawatan untuk mengumpulkan data lengkap, akurat dan 
nyata, harus dilakukan lebih mendalam dan secara sistematis terutama dengan metode wawancara.tidak hanya berfokus pada catatan medis dan anggota tim kesehatan lainnya melainkan harus divalidasi dan ditinjau lebih mendalam agar pengkajian yang dilakukan lengkap, akurat, dan sesuai kenyataan.

\section{Daftar Pustaka}

Djami, M. E., \& Indrayani. (2013). Asuhan Persalinan dan Bayi Baru Lahir. Jakarta: TRANS INFO MEDIA.

Antini, A., Darwanty, J., \& Trisnawati, I. (2016). Efektifitas senam kegel terhadap waktu penyembuhan luka perineum padaibu post partum normal. Jurnal penelitian kesehatan suara forikes .http://lib.Puspasari.pdf

Asiyah, N. (2016). Perbandingan lamakala II dan berat badan lahir terhadap kejadian ruptur perineum. Universty research colloquium

2016 .https://publikasiilmiah.ums.ac.id

Indriyani, D. (2013). Keperawatan Maternitas Pada Area Perawatan Antenatal. Yogyakarta: Graha Ilmu.

Kartini, A. (2016). Hubungan berat badan lahir dan paritas dengan ruptur perineum pada persalinan spontan di puskesmas puter provinsi jawa barat 2009. penelitian dan PKM kesehatan.

Rahayu, P. P. (2016). Faktor yang berhubungan dengan kejadian ruptur perineum dipuskesmasmergangsan kota yogyakarta tahun 2014. Jurnal medika respatihttp://journal.respati.ac.id

Syahrir, Agusyanti, Nurmiyati Ernawati.P, \& Gasang (2015).Profil Kesehatan Sulawesi Selatan 2015, Makassar :
Dinas Kesehatan Provinsi Sulawesi Selatan.http://www.depkes.go.id

Suryani. (2013). Faktor-faktor yang berhubungan dengan ruptur perineum pada persalinan normal di rumah sakit bersalin atiah. Kesehatan .http://ejurnal.poltekkes-tjk.ac.id

Yugistyowati, A., Prawitasari, E., \& Sari, D. K. (2015). Penyebab terjadinya ruptur perineum pada persalinan normal di RSUD Muntilan kabupaten magelang. Journal Ners and Midwifery Indonesia .http://ejournal.almaata.ac.id

Saputra, L. (2013). Kebutuhan Dasar Manusia. Tangerang Selatan: Binarupa Aksara.

Saputra, L., \& Lockhart, A. (2014). Asuhan Kebidanan Masa Nifas Fisiologis \& Patologis. Tangerang Selatan: Binarupa Aksara.

Sudarti, \& Sukarni, I. (2014). Patologi Kehamilan, Persalinan, Nifas, dan Neonatus Resiko Tinggi. Yogyakarta: Nuha Medika

Kementrian Kesehatan (2016). Laporan Kinerja Kementrian Kesehatan Tahun 2015. Jakarta : Kemenkes RIhttp://binfar.kemkes.go.id/2015/01/re ncana-strategis-kementerian-kesehatantahun-2015-2019

Maftuchan, A. (2016). Buku Panduan Jurnalis Isu Kesehatan, Jakarta : Prakarsahttp://theprakarsa.org.pdf

Kementrian Kesehatan Republik Indonesia (2013).Buku Saku Pelayanan Kesehatan Ibu diFasilitas Kesehatan Dasar dan Rujukan, Jakarta : Unicefhttp://www.depkes.go.id 